\title{
THE OCCURRENCE OF PETRODUS AND OTHER FOSSIL SHARK REMAINS IN THE PENNSYLVANIA OF IOWA
}

\author{
by Gerard R. Case \\ Jersey City, New Jersey
}

Gerard Ramon Case has been active in the field of paleontology for the past eight years. His specialty is the study of fossil elasmobranchs (sharks, skates, rays and sawfishes). He has written several articles on this subject as well as on other related natural history subjects. Mr. Case has also written two fossil booklets which are popular with the amateur fossil collectors throughout the world. Currently, he is working on the sharks of Iowa and Nebraska and is in the process of publishing a new booklet on primitive sharks. Mr. Case has had two fossils named after him- the Paralbula case $i$ and the Isobuthus casei-and a few more fossils are in the process of being studied and eventually they will also be named after him.

Abstract: Recent studies into the Hertha Limestone Member of the Bronson Group, Missouri Series of the Upper Middle Pennsylvanian in two principal localities in Iowa have yielded some previously unknown occurrences for fossil vertebrate remains in this state. The fauna comprises cladodontids, edestids, and bradyodontids. The primary interest of this article is the presence of three-dimensional dermal denticles ascribed to the little known shark genus, Petrodus.

\section{Introduction}

Various Carboniferous black shales overlying coal seams in the United States and Europe have produced dermal denticles of the organ genus Petrodus. Occurrences of Petrodus in the coal shales in the United States are rather common, especially in such states as Pennsylvania, Ohio, Indiana, Illinois, Iowa, Missouri and Kansas. Occurrences for threedimensional Petrodus granules, however, are not as common. It is for this reason that the material reported here is significant. 
In 1848, M'Coy described shark skin granules from the Carboniferous Derbyshire Limestones of England under the name Petrodus patelliformis. These dermal denticles belong to an unknown type of shark whose skeletal remains are yet to be found in any limestone or shale outcropping, but whose histological structure indicates an edestid derivation. Although M'Coy's work is over one hundred years old, nothing new has been added to our knowledge of these unusual denticles. A recent renewal of interest in occurrences of this material has been inaugurated in Great Britain and the United States. A summary of occurrences in the state of Oklahoma was made by Carl C. Branson for the Oklahoma Geological Survey (Branson 1965). Branson's occurrences for Petrodus are in several limestones and phosphatic nodules in various counties in the east-central part of the state. A revival of interest in the Carboniferous of England by both Moy-Thomas and Trevo D. Ford has uncovered more specimens from the original M'Coy localities (Moy-Thomas 1935b), (Ford 1964).

The present localities in the state of Iowa where Petrodus denticles have been recovered are: a roadcut exposure of the Hertha Limestone, 2/2 miles north of the town of Stuart (Sec. 20, R-30-W, T-78-N), in Guthrie County. In the same general vicinity, two other fossiliferous outcroppings are found, namely, in a roadcut exposure next to the farm of Mr. Alvin Kopaskas (Sec. 10, R-30-W, T-78-N) and an exposure in the banks of the Deer Creek River (Sec. 15, R-30-W, T-78-N). Since these above localities are all in the same general area, they should be considered as one major locality for this county occurrence. The second major locality in Iowa is situated on a farm property near the town of St. Charles, in Madison County. The exposures here on this farm are found in gulleys on eroded land. The county map for Madison shows this exposure as; Sec. 23, R-26-W, T-75-N.

Both exposures of the Hertha Limestone at the Stuart locality (localities) and at St. Charles, dip northerly thirty-five degrees. It is in the clay below the limestone ledges that the Petrodus denticles and the remains of other elasmobranchs 
are found. The Hertha Limestone ledge range between four and five inches in thickness at each locality with a clay contact zone below containing Mesalobus mesalobus to a depth of three inches. In direct contact below this shell layer of clay is a thin argilaceous seam not more than one inch in thickness which contains the vertebrate remains. In this argilaceous zone the abundant fossil is the Petrodus granules. In addition to these denticles the following related elasmobranch material has been collected: Listracanthus spines, Petalodus allegheniensis, Campodus (Agassizodus) variabilis, Protopirata (Edestus) crenulata, Deltodus sp., Orodus sp. and Cladodus elegans. Two isolated dermal denticles of Holmesella were recently discovered at Stuart, Iowa, extending the vertebrate fauna ensemble. Below the vertebrate layer is a five inch clay-sandstone layer containing more shell material. Below this five inch clay shell-bearing layer is the contact zone for the Des Moines Series, Middle Pennsylvanian coal shales.

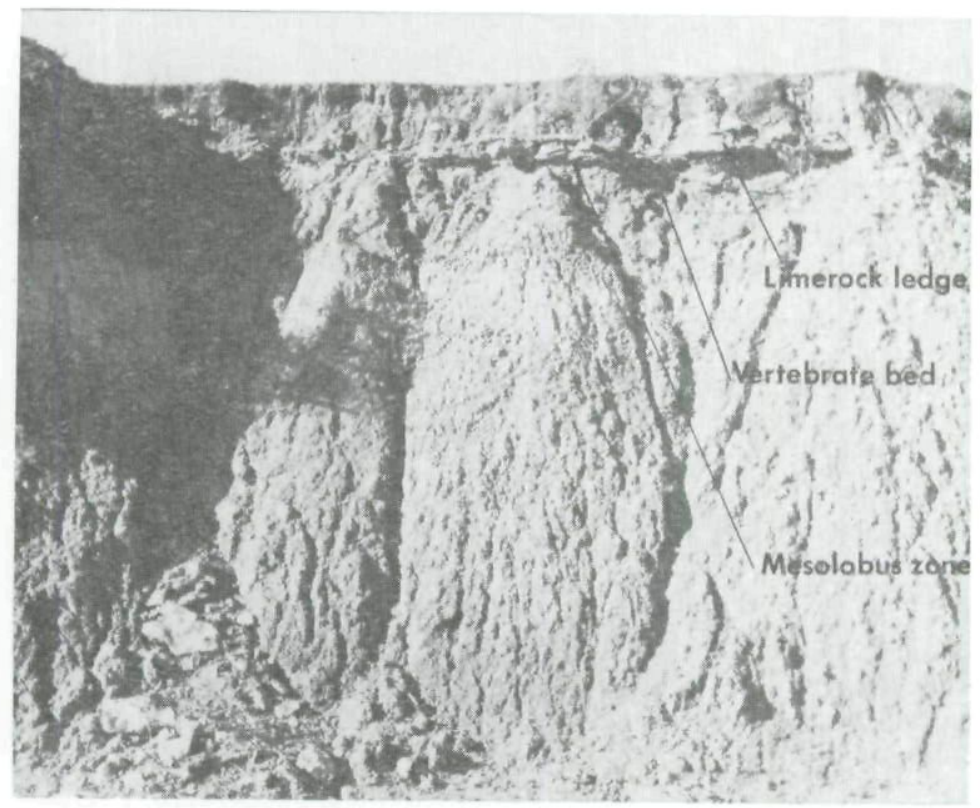

Exposure of Hertha Limestone (Upper Middle Pennsylvanian) in a farmland eroded gully area. St. Charles, lowa, Madison County. 
The Hertha Limestone ledge contains a standard Pennsylvanian marine invertebrate fauna comprising: crinoid columnals, Jurasania sp., Desmoinesia sp., Chonetes sp., Composita subtilita, Derbyia, Mesalobus mesalobus, Dictyoclostus, bryozoan fragments, and cup corals. Several specimens of Orbiculoidea were found in the float at St. Charles, Iowa; and even though divorced from their original position in the limestones or clays, it is strongly suggested that their derivation is from the Hertha Limerock ledge.

There is the possibility that there exist other localities in the state of Iowa for Petrodus and its allied vertebrate fauna, but so far, only the two listed localities for their occurrence are known at the present time.

\section{Acknowledgements}

The author wishes to express his thanks to Mr. Jack Musgrove, Curator, Iowa State Department of History and Archives, Des Moines, Iowa for his assistance with both specimens and information on the Stuart, Iowa localities and to Mr. John Phipps, Preparator, of the same institution, for his similar assistance. The author wishes to especially thank Drs. Donald Baird, Princeton University and Jiri Zidek of Edmonton, Alberta, Canada for their kindness in reading the manuscript and offering suggestions for the betterment of this paper. Photographs by Mr. Tod Fujihira, New York City.

Note: The fossil material relative to this article has been donated to the collections of the Iowa State Department of History and Archives at Des Moines, Iowa.

\section{References cited}

Branson, C. C., 1965. Petrodus in Oklahoma. Oklahoma Geol. Notes, Oct., pp. 274-275, 3 figs.

Ford, T. D., 1964. A new fish bed in the Carboniferous Limestone of Derbyshire. Mercian Geologist, v. 1, pp. 3-9, 1 pl. 2 text-figs.

M'Coy, F., 1848. On some new fossil fish of the Carboniferous period. Ann. Mag. Nat. Hist., (2), v. 2, pp. 115-133. London. Moy-Thomas', J. A., 1935b. On the Carboniferous shark, Petrodus Patelliformis M'Coy. Proc. Leeds Philos. \& Lit. Soc., 3, pp. 68-72, 2 figs, 1 pl. 


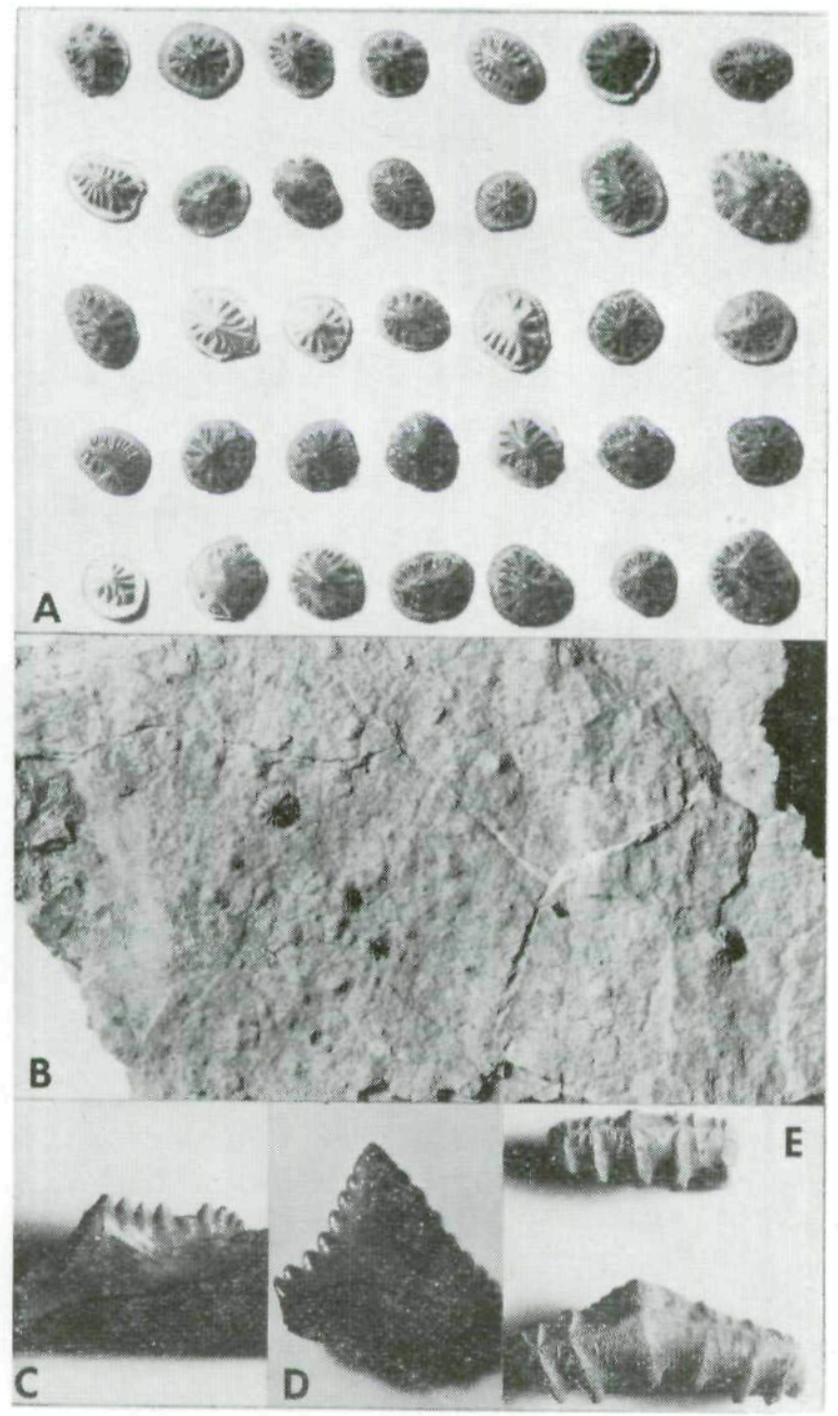

A). Typical PETRODUS dermal denticles.

B). PETRODUS denticles in argilaceous matrix.

C \& D). PROTOPIRATA (EDESTUS) CRENULATA teeth with jaw fragments.

E). CAMPODUS (AGASSIZODUS) VARIABILIS crusher teeth. 
Copyright of Annals of Iowa is the property of State of Iowa, by \& through the State Historical Society of Iowa and its content may not be copied or emailed to multiple sites or posted to a listserv without the copyright holder's express written permission. However, users may print, download, or email articles for individual use. 